\title{
A internacionalização da regulamentação sanitária
}

The internationalization of the sanitary regulation

Geraldo Lucchese 1

1 Escola Nacional de Saúde Pública, Fiocruz. Câmara dos Deputados, Consultoria Legislativa, Gabinete 39B, 70160-900, Brasília DF.

gelucchese@yawl.com.br
Abstract This article discusses the healthrelated agreements that are part of the General Agreement on Tariffs and Trade, $\mathrm{M}$ arrakech, 1994, as well as other international processes in the harmonization of technical regulations. It is based on a literature review aimed at a theorical basis for identifying principles and arguments, in the wording of the agreements and regulations. A special focus is placed on the impacts for Brazilian institutions in terms of internal democracy and national sovereignty. The article concludes that despite the "globalist" arguments according to which these agreements and processes define certain procedures and rules for all states and thus mean a step forward in relation to the previous situation, the international system is still essentially anarchic, with national states moti vated exclusively according to their own interests. The super-powers enjoy the prerogative of interpreting their duties and obligations with no fear of contradiction or retaliation, despite institutionalization at the international level.

Key words Sanitary agreements, Technical barriers, Sanitary regulation, Globalization
Resumo Discutem-se os acordos de interesse sanitário que fazem parte do A cordo Geral de Tarifas e Comércio (GATT, M arrakech,1994), e outros processos internacionais de harmonização de regulamentos técnicos. Parte-se de uma revisão bibliográfica para identificar pressupostos e argu mentos nos textos dos acordos e regulamentações. Consideram-se os impactos, em nossas instituições, quanto à democracia interna e à soberania. Conclui-se que, não obstante argumentos "globalistas" de que esses acordos e processos significam avanço em relação à situação anteri or, o sistema internacional éainda essencialmente anárquico e os estados, motivados pel os seu interesses. As maiores potências têm a prerrogativa de interpretar responsabilidades e obrigações sem medo de contradição ou retaliação, em que pese a existência de uma institucionalização no plano internacional.

Palavras-chave Acordos sanitários, Barreiras ao comércio, Regulamentação sanitária, Globalização 


\section{Introdução}

Embora muito utilizado em textos, debates e conversas dos dias atuais, o termo globalização não é um conceito de fácil definição. Para Shah (2001), a globalização se traduz na transformação do mundo em um espaço compartilhado mediante conexões globais na economia, na política, na tecnologia, nas comunicações e no direito. Essas conexões ensejariam uma crescente separação entre os produtos e a sua manufatura e entre os serviços e a sua localização. Também produziriam um aumento da permeabilidade das fronteiras e uma redução da influência dos instrumentos de política nacional.

Hirst e Thompson (1998) afirmam que, não obstante sua ampla aceitação e uso generalizado, existem diver sas conotações de significado para o termo, cada um expressando um ponto de vista ou enfatizando mais ou menos alguma das características do processo de internacionalização das economias nacionais.

O ponto de vista mais disseminado corresponderia a uma interpretação extremada do fenômeno de maior interdependência entre as nações, ao afirmar que: 1) a maior parte da vida social está determinada por processos globais, o que faz dissolver culturas, economias e fronteiras nacionais; 2) uma economia realmente gl obal emergiu em suas dinâmicas bási cas e é dominada por forças de mercado incontroláveis, uma vez que seus principais agentes são empresas transnacionais, as quais não devem lealdade a nenhuma nação e se estabelecem em qualquer parte do mundo que ofereça melhores vantagens de mercado. Essa versão "dura" da globalização é poderosa, conquistou anal istas e políticos e tem o efeito de paralisar estratégias nacionais de reformas mais radicais por medo dos julgamentos edas sanções dos mercados internacionais.

Outros pontos de vista menos extremados e mais matizados percebem e analisam ten dências à internacionalização a partir de uma perspectiva histórica, admitindo as mudanças atuais, mas assinalando que não constituem novidade e não implicam necessariamente um movimento inexorável para um novo tipo de sistema econômico. Esses enfoques concentram-se na internacionalização dos principais mercados financeiros, da tecnologia - em particular, a da informação e comunicação - e de alguns importantes setores da indústria e serviços, porém enfatizam também as restrições crescentes à governabilidade nacional, notadamente, quando as políticas macroeconômicas são significativamente divergentes das normas aceitáveis pelos mercados financei ros internacionais.

Enquanto a versão "dura" da globalização exige nova compreensão da economia internacional na medida em que subordina processos de nível nacional, a versão das tendências à internacional ização acomoda u ma vi são modificada do sistema econômico mundial, que ainda atribui papel importante às políticas e atores nacionais.

Destacando a necessidade da diferenciação entre esses diferentes pontos de vista relacionados à tese da globalização porque confundem tanto a discussão pública quanto a elaboração de políticas, Hirst e Thompson (1998) vêem com ceticismo a versão extremada, por não identificarem, em sua análise, fundamentos para as declarações dos partidários mais radicais da globalização.

Em qualquer das hipóteses, esse movimento da globalização acarreta mudanças de comportamento e na estrutura de empresas, de governos e de agências internacionais, as quais, entretanto, podem usar instituições e práticas de diferentes formas. A tese dos autores é a de que existiria muito mais espaço e possibilidades de estratégias e de ações políticas para o controle nacional e internacional das economias de mercado em direção a metas sociais do que a versão "dura" da tese da globalização faz crer.

Castels (1999) defendequeum mundo novo teria tomado forma neste final e início de milênio, originado na confluência de três processos independentes: 1) revolução tecnológica da informação; 2) crise econômica do capitalismo e do estatismo (bloco comunista), com a conseqüente reestruturação de ambos; e, 3) apogeu de movimentos socioculturais, tais como os de libertarismo, direitos humanos, feminismo eambientalismo. A tecnologia da informação - base material dessa nova sociedade e mecanismo indispensável aos processos de reestruturação econômica - seria o elemento principal da geração de riqueza, do exercício do poder e da criação de códigos culturais. Exerceria também um papel de especial importância na formação de redes como modo dinâmico e auto-expansível de organização da atividade humana, o que teria transformado todos os domínios da vida social eeconômica. 
Essas redes de capital, de trabal ho, de informação e de mercados teriam conectado funções, pessoas e locais com valor de mercado em todo o mundo, ao mesmo tempo em que desconectaram as populações e territórios desprovidos de valor e de interesse para a dinâmica do capitalismo global. Com o fim do estatismo, o capitalismo teria aumentado rapidamente sua penetração nos países, nas culturas e nos domínios da vida e, pela primeira vez na história, todo o planeta estaria organizado com base em um conjunto de regras econômicas comuns apesar da diversidade social e cultural do mundo.

Entretanto, não apenas regras econômicas tendem a adquirir abrangência global. A regulação sanitária segue a mesma ten dência, absorven do todos os matizes dessa nova realidade da regulamentação, da inclusão ou exclusão do mercado internacional, de maior ou menor espaço às políticas nacionais de controle do mercado e assim por diante.

Longe da suficiência do Estado mínimo e da regulação simples pelo mercado - como prega a tradição liberal mais ortodoxa -, a realidade atual está a exigir uma intervenção estatal de novo tipo, mais efetiva e eficiente diante dos riscos e ameaças que também se globalizam de maneira acelerada. 0 Estado, nos países de economia avançada, envolve-se cada vez menos no sistema produtivo. No entanto, exerce intensa atividade regulatória, manten do consistente aparato técnico-burocrático para regular, fiscalizar e disci plinar o mercado.

Processos internacionais de regulamentação são crescentemente instituídos em todos os campos da vida social e econômica. $\mathrm{Na}$ área da saúde, as medidas de qualidade e de padrões mínimos de segurança são constantemente aval iadas e exigidas (Bodstein, 2000). D a mesma forma, são cada vez mais definidas em foros globais com a intenção de ter ascendência sobre to dos os estados.

No plano da economia, uma das mais marcantes características da gl obal ização é, certamente, a derrubada das fronteiras al fandegárias, por meio da extinção, equiparação ou diminuição dos impostos aduaneiros. A abertura ao comércio internacional constituiu-se em um dos principais objetivos do A cordo Geral de Tarifas e Comércio (General A greement on Tariffs and Trade- GATT), uma instituição criada em 1947, no contexto dos entendimentos do pós-guerra, no Tratado de
H avana, em paral elo à intenção de se criar a Organização Internacional do Comércio.

Um pouco antes, em 1944, nos A cordos de Bretton W oods, assinados por 44 estados aliados, haviam sido criados o Fundo M onetário Internacional (FMI) e o Banco Internacional para a Reconstrução e o D esenvolvimento (BIRD). Era um contexto de busca de regulamentos para o funcionamento mais harmônico do sistema econômico internacional, bem como de entendimentos para o melhor diálogo entre as nações dentro de uma nova ordem mundial.

Enquanto o FMI trataria da questão das taxas de câmbio e do sistema monetário internacional, o BIRD, mais conhecido como Banco M undial, se ocuparia da reconstrução e desenvol vimento dos países devastados pela guerra. Por sua vez, o GATT surgia como instância regulamentadora, com a preocupação de reduzir os obstáculos aos intercâmbios internacionais, por meio da diminuição das tarifas aduaneiras e de outros tipos de barreiras, e da eliminação das discriminações em matéria de comércio internacional.

As sucessivas rodadas de negociação do GATT permitiram que os países chegassem a reduções substanciais dos direitos de aduana, ou seja, um abrandamento significativo das barrei ras alfan degárias ao comércio internacional. As últimas rodadas - Tóquio (1973 a 1979) e U ruguai (1986 a 1994) - instituíram os acordos relativos a barreiras não alfandegárias.

No plano do comércio internacional, 0 incremento do volume de produtos manufaturados submetidos a controles não tarifários menos de $1 \%$ em 1974, para cerca de $20 \%$ em 1985 (M ilner, 1997b) - fez aumentar a importância das instituições relacionadas com a regulação sanitária. Eles mostram que, enquanto diminuiu o uso de restrições tarifárias ao comércio internacional, conforme os avanços do GATT, aumentou o uso de restrições não tarifárias, principalmente aquelas de natureza sanitária.

Ter-se-ia intensificado a preocupação da comunidade internacional, principalmente, a dos países mais industrializados, com o risco sanitário e com a saúde das populações do mundo? Ou o crescimento da importância das instituições regulatórias internacionais estaria relacionado, antes, no contexto da liberação econômica mundial, à possibilidade do uso de medidas sanitárias como barreiras 
disfarçadas ao comércio internacional?

N este artigo, apresento uma revisão bibliográfica na busca de uma base teórica que ajude a identificar os pressupostos e argumentos implícitos ou explícitos em alguns desses acordos e processos de regulamentação internacional, que apresentam importância para a atividade de controle sanitário.

Analiso, em especial, o Acordo sobre Aplicação de M edidas Sanitárias e Fitossanitárias (AM SF) e do Acordo sobre Barreiras Técnicas ao Comércio (BTC) - acordos componentes da "A ta Final em que se incorporam os resultados da Rodada U ruguai de N egociações Comercialis M ultilaterais" do GATT, assinada em abril de 1994, na Reunião de M arrakech, M arrocos. Essa A ta inclui o Acordo Constitutivo da Organização Mundial do Comércio $(O M C)$, órgão com personalidade jurídica internacional e estrutura própria para conduzir as relações comerciais entre seus membros com base nos acordos firmados.

$\mathrm{Na}$ parte final do artigo, aponto outros acordos internacionais, em vigência ou discussão, que têm grande importância para a saúde por tratarem de riscos provenientes de (sérias) questões sanitárias ou ambientais. Também aponto processos internacionais de harmonização de regulamentos técnicos sobre produtos de interesse para a saúde que, embora mais próximos dos órgãos nacionais e internacionais de saúde, são mediados pela mesma lógica que preside os acordos internacionais de não criar constrangimentos ao comércio internacional.

\section{Internacionalização einstitucionalização}

Conforme Keohane e M ilner (1996) ressaltam, não se pode mais entender as políticas nacionais sem compreender a natureza dos vínculos entre as economias nacionais e a economia mundial, além das mudanças que ocorrem em tais vínculos. As modificações nos custos de tran sação, que levam o capital a movimentar-se por mel hores oportunidades nas taxas de juros e de câmbio, ocasionam profundos efeitos nas condições econômicas e políticas nacionais.

Esses autores, ao analisarem os vínculos entre a internacionalização da economia e as políticas internas, consideram que a internacionalização afeta os interesses políticos dos atores internos por expandirem os setores econômicos mais internacionalizados e reduzirem a atividade econômica dos setores mais protegidos das forças do mercado, produzindo simultaneamente um aumento da sensibilidade das economias nacionais às tendências e choques do mercado mundial.

Ao afetar os interesses políticos dos diferentes atores sociais, a internacionalização tem produzido mudanças nas coalizões, nas políticas, e nas instituições domésticas. Os atores políticos respondem tanto aos limites e possibilidades impostos pela economia mundial, quanto aos incentivos e restrições inerentes às instituições nacionais existentes. $\mathrm{Ou}$ seja, os resultados políticos dos efeitos da internacional ização econômica não são previsíveis simplesmente tomando-se por base os interesses econômicos. Os jul gamentos estratégicos, as manobras políticas, os processos institucionais ou as pressões por radicais mudanças institucionais, entre outros fatores exógenos, fazem parte das decisões. $\mathrm{Não}$ importa o grau, ou a seriedade, do impacto da internacionalização sobre os interesses dos atores; esse im pacto sempre será mediado por fatores políticos domésticos, os quais refletem a diversidade das experiências históricas.

Os autores, ao perceberem que a internacionalização afeta as políticas e instituições de forma diferente em cada país na depen dência do contexto institucional, introduzem outra variável de análise: as instituições políticas que podem bloquear e refrear os efeitos da internacionalização - entre outras, a força dos sindicatos, as regras eleitorais, o número de atores com poder de veto e o grau de independência política de setores-chave da burocracia, como os bancos centrais.

Para M ilner (1997a), as instituições têm significativo impacto no plano doméstico da tomada de decisões. Elas determinam quais atores têm maior influência no processo político e as preferências que serão assumidas. Em relação aos efeitos da política doméstica nas relações internacionais, a autora destaca três fatores internos principais: a estrutura dos interesses domésticos, a natureza das instituições políticas domésticas e a distribuição interna da informação (M ilner, 1997a).

Ao estudar os casos dos EUA, da França e da Inglaterra, M ilner (1997b) ressal ta que os diferentes arranjos - ou modelos de organização e de relação entre o legislativo e o executivo e as diferentes organizações da admi- 
nistração pública e funcionamento da burocracia civil - fazem a diferença dos impactos das políticas de comércio internacional sobre os atores domésticos.

D estacando que França e Inglaterra, por fazerem parte da U nião Européia, têm grande parte de sua agenda decisória deslocada para os órgãos comunitários supranacionais, M ilner aponta que, nesses três países, a natureza dos grupos de interesses domésticos, os objetivos políticos das el ites e as restrições do sistema internacional exercem fortes influências sobreo processo decisório interno.

0 deslocamento cada vez maior dos debates e decisões para fóruns internacionais traz uma série de implicações na questão da democracia interna. 0 caso brasileiro parece confirmar a avaliação de Cox (1997), quando afirma que uma das conseqüências da globalização econômica - que diminui os controles governamentais no tocante às economias nacionais - seria a de transformar os políticos do nível nacional em gerentes. A política, no sentido da construção e da escolha entre al ternativas oriundas de projetos rivais, não teria mais cabimento dentro da estrutura de pensamento da global ização econômica. Para os países periféricos, em particular, a tomada de decisões seria realizada cada vez mais em fóruns internacionais ou moldada pelas imposições de agências, organismos e regimes internacionais comandados pelos estados centrais.

Os programas de ajuste estrutural introduzidos pelo Fundo M onetário Internacional nos países endividados - quase todos os periféricos - tornaram-se o principal método para promover a globalização econômica nestes países. 0 receituário aplicado é sempre semeIhante e vai desde a redução das barreiras ao comércio internacional até os cortes nos gastos públicos com programas sociais. M odelos de economia e sociedade al ternativos são excluídos. 0 trabalho a fazer é um só e a política interna fica reduzida à competição entre os políticos para mostrar quem é mais eficiente para realizá-lo (Cox, 1997).

$\mathrm{N}$ a concepção desse autor, as conseqüências para a democracia podem ser trágicas. A população torna-se cada vez mais cética em rel ação à política e aos políticos, que parecem ser incapazes de resolver os problemas básicos, como o desemprego, a deterioração dos serviços públicos e a corrupção, entre outros. A democracia compatível com a globalização econômica gera ceticismo naqueles prejudicados pela exclusão do mercado e, se leva à apatia cívica, por um lado, pode levar, por outro, a atividades extraparlamentares, muitas vezes, ilegais ou negativas, como o aparecimento de grupos neonazi stas, que protestam contra o emprego dos estrangeiros em seus países, de grupos organizados para a violência e o crime eassim por diante.

0 declínio da confiança pública nas autoridades políticas tradicionais, a apatia, o cinismo ea despolitização deixam um espaço livre entre as altas posições dos governos e a fragilizada sociedade civil, o qual é ocupado por atores ocul tos, aventurei ros e criminosos dificilmente controláveis por uma transparente autoridade pública. N essecenário, a confiança pública no processo democrático fica enfraquecida; assim, a tendência de fragilização da democracia liberal parece mais provável do que as perspectivas de seu aperfei çoamento (Cox, 1997).

Segundo Putnam (1988), os grupos nacionais pressionam o governo para que realize políticas de acordo com seus interesses e buscam poder para isso, formando coalizões políticas; no nível internacional, o governo busca maximizar sua habilidade para satisfazer os grupos domésticos e minimizar as conseqüências dos compromissos externos. 0 conflito interno acontece em torno da definição do queé o interesse nacional para cada grupo.

Há consenso entre muitos autores (cf. Held, 1995; Rosenau, 1995; Cox, 1997; Krasner, 1995, entre outros) de que a soberania ea autonomia dos estados-nação está sob severa pressão em muitos locais. Essa pressão é exercida, por um lado, pela estrutura do sistema internacional - em particular, a organização da economia global, isto é, empresas transnacionais, produção difusa, mercado financeiro, mercados nacionais mais abertos e assim por diante - e, por outro, pelas políticas e atividades das agências e organizações, regionais ou internacionais, como a União Européia, o Fundo Monetário Internacional, o Banco Mundial, e agora também os acordos do GATT através da Organização M undial do Comércio, entre outros.

Segundo H eld (1995), existem ainda os regimes internacionais - princípios, normas, regras e procedimentos de decisão pelos quais as expectativas dos atores convergem em dado assunto das relações internacionais - , os 
quais, junto com as organizações internacionais, têm levado a importantes mudanças na estrutura de tomada de decisões da política mundial. Para ele, qualquer concepção de soberania que a afirme indivisível, ilimitada, exclusiva e perpétua forma de poder público, corporificada em um estado individual, está sepultada. Held aponta o aumento dos foros de decisão coletiva entre governos: de 37, em 1909, para 300, em 1989; e também das organizações não-governamentais ( ON Gs) internacionais - de 176, em 1909, a 4.624, em 1989 - para afirmar a crescente importância da comunidade internacional em detrimento dos estados nacionais.

Rosenau (1995) ressalta que as fronteiras dos estados nacionais não mais conseguem confinar o fluxo de informações, bens, dinheiro e pessoas. Ao contrário, para ele, o processo de globalização tornou-se predominante e, mesmo, permanente. 0 autor identifica uma variedade de ten dências e de conteúdos que apontam para o declínio da efetividade do Estado, como certa erosão de sua autoridade e um correspondente aumento na competência de organizações internacionais, que ultrapassam os reclames estatais de plena jurisdição acerca de seus afazeres domésticos.

Essa mesma linha de raciocínio argumenta que uma fundamental mudança estaria ocorrendo e sugere a possibilidade de que o longo período de estabilidade do conceito de soberania estaria chegando ao fim. 0 Estado não mais deteria o monopólio do respeito de seus cidadãos, que agora buscam outras instituições para o suprimento de suas necessidades básicas. Indica, ainda, que a mai oria dos estados, na forma como estão constituídos, não teria meios para realizar plenamente os objetivos essenciais de prover segurança e bem-estar a seus habitantes.

Kratochwil (1995) acrescenta que, à semeIhança da propriedade - conceito igualmente construído socialmente-, a soberania implica não somente direitos, mas, também, responsabilidades. Por conseqüência, há limites para a soberania, em especial, em rel ação às responsabilidades que os estados soberanos têm com os que eles governam e, da mesma forma, em relação a outros soberanos. Se, no passado, as grandes potências arrogantemente tomavam para si o julgamento da responsabilidade e intervinham conforme seus interesses, atualmente, com a expansão da sociedade internacional, os estados mais podero- sos necessitariam cada vez mais de legitimidade coletiva para fazer interven ções; tal legitimação viria de decisões tomadas em consonância com procedimentos acei tos e normas acordadas de comportamento.

Esses autores, entre outros, manifestam uma visão denominada gl obal ista no cenário das relações internacionais. Para os globalistas, o conceito de comunidade internacional é significativo, pois o mundo seria, cada vez mais, uma única coletividade com interesse global comum. O u seja, os membros da comunidade internacional compartilham um senso de direitos, deveres, valores e obrigações. Assim, as ações internacionais seriam motivadas a proteger ou promover certos valores ou a defender certos princípios enão meramente a defender interesses e valores de estados particulares.

Os globalistas também enfatizam o papel chave das ON Gs, argumentando que elas cresceram tanto, que não faz mais sentido falar dos estad os como atores exclusivos no sistema internacional. Para eles, as ON Gs são atores não estatais da sociedade internacional, que compartilham valores dessa sociedade. Suas participações em intervenções internacionais seriam evidências da crescente importância dos atores não estatais e da natureza mutante da sociedade internacional (Lyons e M astanduno, 1995). Para a tradição globalista, existem evidências suficientes para que se perceba 0 atual momento histórico como 0 início de um longo processo de expansão da autoridade da comunidade internacional.

Por sua vez, a abordagem realista nas relações internacionais preconiza que a sociedade internacional é ainda essencialmente anárquica, ao passo que os estados são motivados pelos seus interesses, enquanto o comportamento e os resultados são determinados pela distribuição de poder entre os estados. Os real istas são céticos quanto ao conceito de comunidade internacional. Em razão disso, eles não vêem razão para pensar que as mudanças observadas pela abordagem globalista alterem essa ordem. Não obstante as mudanças na capacidade de governar dos estados, estes ainda teriam expressivo prestígio, e os estados poderosos continuariam a ter importância ainda maior. Q ualquer intervenção internacional pode ser mais bem entendida em termos de poder e interesses de uma nação particular, em especial, os dos estados mais poderosos. Agindo individual ou coletivamente, os 
estados poderosos disfarçam seus interesses na linguagem do bem comum e justificam sua ação em nome da comunidade internacional. No fundo, são mais guiados pelos cál culos de seus interesses particulares do que por valores compartilhados na comunidade. Constitui-se prática histórica das grandes potências a articulação de seus interesses particulares na linguagem dos princípios universais, em um esforço para persuadir os outros estados a aceitá-los (Lyons e M astanduno, 1995).

Krasner (1995) é autor de ten dência realista efundamenta sua posição em análises de casos passados de intervenções que invocavam o bem comum como justificativa, tais como a estabilidade internacional ou a proteção das minorias. Argumenta que todas aconteceram porque as grandes potências, que são capazes de intervir efetivamente, decidiram fazê-lo sob pressão de seus próprios interesses nacionais ou de importantes interesses domésticos.

No Conselho de Segurança da ONU, um dos maiores expoentes da comunidade internacional, por exemplo, os cinco membros permanentes têm poder de veto, que éusado em favor de seus próprios inter esses.

Entretanto, todos esses autores assinalam as contradições elimites de suas alternativas de abordagens. O próprio Krasner (1995) aponta a insuficiência do realismo para explicar adequadamente as intervenções. Autores globalistas, como H eld (1995), não deixam de perceber que as agências multilaterais real izam os interesses daqueles estados poderosos que mais contribuem para seu sustento. 0 autor assinala que o Banco M undial, por exemplo, encontrou-se envolvido em intenso debate a respeito do direcionamento de suas políticas: se elas seriam baseadas em juízos econômicos ou se representariam uma estratégia derecolonização.

Lyons e M astanduno (1995) destacam que, em acordos internacionais, as maiores potências têm a prerrogativa de interpretar suas responsabilidades e obrigações sem qualquer medo de contradição ou retaliação. N as relações econômicas internacionais, as maiores potências mantêm, através do Grupo dos 7 , sua dominação sobre as agências multilaterais de financiamento e sua influência sobre os mai ores bancos privados transnacionaise as corporações empresariais que operam dentro de seus sistemas regulatórios nacionais.

\section{Os acordos relacionados ao controle sanitário}

Historicamente, os países desenvolvidos sempre adotaram medidas protecionistas na área da agricultura, em especial, por meio de barreiras não tarifárias, al egando motivos ambientais, trabalhistas ou sanitárias. Em razão disso, os países periféricos viram as regulamentações do comércio internacional e das políticas nessa área como vitória.

O Acordo sobre Aplicação de M edidas Sanitárias eFitossanitárias (AM SF) insere-sena série dos acordos multilaterais de comércio de bens, e éfruto do esforço para eliminar restrições ao comércio de produtos agrícolas, estabelecen do regulamentos baseados em referências internacionais de amplo acesso a todos os países-membros.

Seu principal objetivo éa definição de regras para a aplicação de medidas sanitárias efitossanitárias de forma adequada aos princípios do GATT, visando não criar barreiras desnecessárias ao comércio internacional. Tem a sua preocupação voltada para a possibilidade de entrada, estabelecimento ou disseminação de praga ou doença no território do país importador, bem como para os efeitos adversos resultantes do uso de aditivos, da presença de contaminantes, toxinas ou organismos patogênicos em alimentos, bebidas ou ração animal.

O AM SF preserva a autonomia dos membros para queadotem ou apliquem medidasindispensáveisà proteção da vida ou saúde humana, vegetal ou animal, mas enfatiza a necessidade de que sejam fundadas em princípios científicos eque não sejam mantidas sem evidência científica suficiente.

Para evitar a arbitrariedade, 0 acordo prevê que as medidas sanitárias devem fundamentarse em normas, guias e recomen dações de organismosinternacionais. Entretanto, ébastanteflexível para permitir até que um membro adote medidas queresultem em nível mais elevado de proteção sanitária do queaquele que se alcançaria com medidas baseadas em normas, guias erecomendações internacionais, desde que haja justificação científica ou como conseqüência do nível de proteção sanitária que um membro determine ser apropriado (AM SF, art. 3: 3). Em outras palavras, um membro que possua bom aparato e recursos de pesquisa e construção de conhecimento específico pode decidir qual o nível de proteção ad equado a sua sociedade e exigir que os outros países observem tais exigências sanitá- 
rias.

Outra questão desfavorável aos países em desenvolvimento éque, embora tenham direito à plena participação nos organismos internacionais normatizadores, como o Codex Alimentarius, o Escritório Internacional de Epizootias, e outros, a fim de promoverem a elaboração ou a revisão periódica de normas, guias e recomendações a respeito demedidas sanitárias, esses países não têm recursos- principalmente, científicos, humanos e financeiros - para participar em igual dade com os desenvolvidos. As normas erecomendações desses organismos são, quase sempre, resultado de monitoramentos ou de pesquisas toxicológicas onerosas e complexas, realizadas às expensas dos países mais ricos e refletem, para além do conhecimento científico, osinteresses econômicos epolíticos desses países.

A adoção de medidas sanitárias deve-se dar de tal forma que não ponha em risco os interesses comerciais entre os membros. Com o receio deque algum Estado membro use medidas sanitárias como forma de colocar restrições veladas ao comércio internacional ediscriminações arbitrárias ou injustificáveis entre os países, o acordo acaba por instituir uma rigidez científica exacerbada, quelimita o poder da ação sani tária quando o país-membro não tiver sistema de regulamentação e controle sanitário forte, eficiente e ágil, o que éa regra em todos os estados periféricos.

O AM SF estabelece muitos condicionamentos - fundamentos técnico-científicos e procedimentos administrativos ágeis e objetivos, graduais e criteriosos, além de oportunos - à ação autônoma das autoridades sanitárias, o queépositivo sob o ponto de vista do comércio, poisinibe as barreiras não alfandegárias. Porém, sob o ponto de vista sanitário, torna necessário dotar os sistemas de controle de maior qualificação e maior eficiência, em termos deconhecimentos, infra-estrutura, recursos técnicos e força política.

Para não impedir uma ação necessária ao enfrentamento deum risco, mesmo nos casos em que a evidência científica seja insuficiente, 0 acordo permitea ação provisória atéque se obtenham maiores esclarecimentos, via informação adicional ou investigação, para uma avaliação mais objetiva do risco e da conveniência de manutenção da ação.

Sob o ponto de vista da saúde, essa providência é positiva, embora possa prejudicar injustamente a reputação de um produto ou de uma empresa, caso secomprovequeo risco envolvido não tem origem intrínseca no produto ou em seu processo produtivo. Contudo, a interdição ébaseada no primado do interesse sanitário e coletivo, sobre o comercial eo particular, etambém na ascendência da prevenção dos riscos e agravos sobre a ação curativa ou remediadora, devendo ser seguida por toda autoridade pública responsável. A questão éter força, meios, instituiçõese recursos suficientes.

O Acordo criaum Comitêsobre M edidas Sanitárias eFitossanitárias no âmbito da OM C, que servirá de foro para consultas e facilitação das negociações entreos membros por meio de estudose consultas técnicas.

Q uando aborda a responsabilidade de cada Estado membro na implementação do A cordo, o texto surpreende, negativamente, ao enquadrar as $O N G$ saos seus dispositivos. Os governos devem adotar medidas razoáveis que estiverem ao seu alcance para assegurar que essas instituições existentes em seu território cumpram o estabelecido pelo Acordo. Ademais, devem considerar e estimular apenas aquelas que assim o fazem (AMSF, art. 13).

No que se refereao conceito e às funções das ON Gs na sociedade, parece haver aqui uma evidenteinversão de entendimento, pois essas instituições surgiram exatamente em setores nos quais o Estado jamais conseguiu atuar de forma satisfatória junto à sociedade. Fiscalizar as ações estatais pode ser, até mesmo, um dos interessese funções das ON Gs.

As ON Gs significam grupos sociais autônomos, articulados por diferentes convicções e interesses, cuja existência é externa às instituições do Estado. Representam a sociedadecivil em movimento, a qual, como ressal ta Cox (1997), constitui uma camada intermediária entre o indivíduo eo Estado, dos quais se espera a plena participação para construir democracias substantivas que possam regular os movimentos da globalização econômica. Submeter as ON Gs aos termos dos acordos da Rodada U ruguai é uma tentativa deanular ou esvaziar seu trabalho, que, em muitos casos, têm objetos eobjetivos supranacionais.

0 acordo AM SF defineainda como os paísesmembros devem proceder para elaborar epublicar um regulamento ou uma medida sanitária, assim como para realizar ações de inspeção e aprovação de processos, exigindo rapidez nas análises e pronto fornecimento de informações e comunicações aos interessados. Para efeito de transparência, todos os membros devem tomar conhecimento de que um país planeja estabelecer determinada medida ou regulamento sanitá- 
rio, tendo a oportunidade de se manifestar a respeito e de emendar o regulamento proposto. M aisuma vez, éexigida uma infra-estruturaágil e eficiente sob o ponto de vista político eadministrativo, além de competente em termos técnicos, econômicose sociais.

0 outro acordo, o Acordo sobre Barreiras Técnicas ao Comércio (BTC), por sua vez, difere do AM SF por aplicar-se a todos os tipos de produtos, mas tem diretrizes básicas muito semeIhantes. Ou seja, os regulamentos técnicos adotados não podem criar obstáculos injustificadosao comércio internacional e devem ser baseados, sempreque possível, em referências internacionais. Além degarantir tratamento igual aos produtos nacionais e importados, o acordo estabelece que os regulamentos não serão mais restritivosao comércio do queo necessário para realizar um objetivo legítimo tendo em conta os riscos quea não realização criaria (BTC, art. 2; 2.2).

Tais objetivos legítimos relacionam-sea imperativos de segurança nacional; à prevenção de práticas fraudulentas; à proteção da saúdeou segurança humanas, da saúde ou vida animal ou vegetal; ou do meio ambiente, a fatores climáticos ou outros fatores geográficos fundamentais; ea problemas tecnológicos e de infra-estrutura. Há, portanto, uma amplitude de possibilidades de aplicação dos regulamentos que visam aos interesses nacionais, dependendo, para serem adotados, da força edos recursos que cada país tem.

No texto, mereceram detal hada disciplinarização os temas da preparação, adoção e aplicação deregulamentos técnicos enormas; dos procedimentos para avaliação deconformidade; da equivalência de sistemas de aval iação de conformidade eacordos de reconhecimento mútuo; das notificações, bem como o da informação e da cooperação técnica dos países desenvolvidos aosmenos desenvolvidos.

O BTC prevêa criação do Comitê deBarreiras Técnicas ao Comércio na OM C, constituído por um representante de cada país-membro, que terá a principal função de fornecer consultase promover o cumprimento do Acordo. Em anexo, consta um Código de Boa Conduta para a Elaboração, Adoção eA plicação de Normas, o qual repete muitas regras queestão no Acordo na busca de maior racional idade entre os diversos sistemas einstituições normalizadoras, públicas ou não públicas, internacionais, regionais elocais, inclusive, de poderes públicos distintos do governo central dosmembros.

A exemplo do Acordo AM SF, o BTC estabelece que, quando houver ameaça de problemas ur- gentes em termos de segurança, saúde, proteção do meio ambiente ou outros objetivos legítimos, os procedimentos obrigatórios serão simplificados, mas também devem ser notificados aos outros países-membros.

Como foi anteriormenteapontado, a questão da institucionalidadeinterna parece ser fator de bastante importância na análise das conseqüências que os acordos do GATT podem ter no plano doméstico. Nesse sentido, a questão mais importante para o Brasil écertamente a carência estrutural das instituições públicas do país encarregadas de assegurar o cumprimento das disposiç̧ões do acordo na forma em queestão colocadas. $\mathrm{Ou}$, dito deoutra forma, a fragilidadedas instituições políticas brasileiras, que poderiam filtrar emoldar os efeitos da internacionalização no plano doméstico, deixa o Brasil mais vulnerável aos movimentos diretos da atividadeeconômica.

Assim, para "jogar" no processo de regulamentação sanitária internacional, para participar com chances iguais de aproveitar a regulamentação de modo a proteger sua população e promover os seus interesses sanitários eambientais, os países em desenvolvimento deveriam contar com uma estrutura que lhes falta de imediato: de informação, de documentação, de pessoal qualificado em comércio e direito internacional e, também, em diferentestecnologias, de recursos de comunicação e de deslocamento ágeis e eficientes, de argumentação científica ede pesquisa nas áreas de maior importância econômica. Tudo isso solidamente institucionalizado e regulado por uma democracia qualificada econsolidada em instituições políticas, jurídicas, éticas e administrativas sólidas e en raizadas na cultura do país.

O perfil oligárquico e patrimonial da administração pública brasileira, a precária consistência técnica eadministrativa da maior parte da burocracia estatal, a instabilidade e descontinuidade administrativa, os baixos salários, a falta de pessoal qualificado ea precariedade dos recursos financeiros, por exemplo, representam óbices intransponíveis, em curto prazo, para que o Brasil possa cumprir os termos dos acordos.

Pode-se inferir, a partir dos preceitos de M ilner edeCox, que, em termos sanitários, os acordos do GATT expõem demaneira mais explícita a vulnerabilidade do país pela precariedade da mediação quesuas instituições podem fazer para filtrar emoldar os efeitos da internacionalização no plano doméstico. Quanto menos pluralista, quanto menor a força de suas instituições, quanto menor o grau da democracia de uma nação - 
que é a unidade do sistema internacional -, maior será sua globalização, no sentido passivo do termo.

Com o crescimento da importância da economia internacional, verifica-se a concentração depoderes em certas arenas, como as do FM I, do BID, do G-7 e, agora, da OM C. M uitos temas da agenda interna são tratados nas agendas internacionais desses organismos multilaterais, em especial quando se trata de países periféricos, em virtude da importância de suas dívidas com a maioria desses organismos. Com isso, ocorreautomaticamente um fortalecimento do Poder Executivo, que éa autoridade representante do Estado e o negociador frentea esses agentes e aos outros estados vistos como outras unidades do sistemainternacional.

Nesse aspecto, o poder queinova éo Executivo, pois éeleo ator que vai às frentes internacionaisetem maior grau deliberdade de ação. Ademais, toda negociação internacional pretende transformar-se, de al guma forma, em política pública implementada pelo Executivo de cada país.

Segundo Putnam (1988), uma das principais atribuições do Estado seria gerenciar a dicotomia queseforma entreas demandas por políticas públicas internas eas negociações internacionaisos jogos de dois níveis - , não cedendo necessariamente soberania ou democracia. Com a internacionalização crescente da economia e das agendas, o jogo democrático torna-se mais complexo, poistoda negociação internacional deve ser pensada na possibilidade da aprovação doméstica.

Com efeito, a certeza da ratificação interna do acordo ou compromisso assumido externamenteéfundamental para o Executivo. Sem essa capacidade, seu poder debarganha, como negociador, se enfraquecemuito. Conseqüentemente, o custo, para o Legislativo, de não ratificar um acordo feito ou um compromisso assumido pelo Executivo émuito alto. 0 déficit para a democracia interna parece evidente. 0 espaço da representação dos segmentos sociais constitutivos da nação - baseada nos princípios da soberania e territorialidade - fica com campo limitadíssimo departicipação nestas decisões que, sem dúvida, ditam o rumo da inserção do país no contexto internacional.

0 processo de ratificação dos acordos do GATT no parlamento nacional representa um emblema da antinomia existente entre a democracia interna e os compromissos internacionais.

0 presidente da República do Brasil, como chefe deEstado, no exercício de sua competência constitucional de conduzir a política externa do país e de representá-lo peranteestados estrangeiros e organismos internacionais, submeteu ao Congresso N acional os textos dos acordos constitutivos da Ata Final da Rodada U ruguai de $\mathrm{Ne}$ gociações M ultilaterais.

Cabeao Congresso Nacional, conformemanda o artigo 49 da Constituição Federal, resolver definitivamentetratados, acordos ou atosinternacionais que acarretem encargos ou compromissosgravosos ao patrimônio nacional. A apreciação detal acordo internacional constitui tarefa das duas casas legislativas, primeiramente da Câmara dos Deputadose, depois, do Senado $\mathrm{Fe}$ deral, como casa revisora. Ao Parlamento, como legítimo representante da soberania popular, caberia o criterioso exameea avaliação do real conteúdo dos direitos, obrigações e compromissos internacionais implícitos no referido acordo e sua manifestação representaria a vontade do povo brasileiro. Depois de aprovado o ato internacional pelo Congresso através de decreto legislativo, ficaria ele ratificado, podendo o chefe do Estado assumir legitimamente os compromissos internacionais (Fontanive, 1994).

Por esses motivos, em razão da complexidade da matéria e pelo el evado grau de compromissos assumidos e de interferências nas políticas eregulamentações nacionais, seria de esperar que o Congresso $\mathrm{N}$ acional procedesse a uma análise bastante criteriosa, em tempo adequado, buscando conhecimentos mais aprofundados acercados efeitos- de ordem política, econômica ou social - decorrentes da adesão do país ao acordo.

No entanto, não era esseo espírito da ação do Congresso Nacional. Os longos e complexos acordos da Rodada U ruguai não seriam analisados em cada um de seus mandamentos. Foram frutos de sete anos de difíceis negociações entre centenas de representantes dos países-membros. Alguns acordos, como o da agricultura e o dos têxteis, representavam mais do queisso, poisforam buscados duranteos 47 anos de vigência do GATT em suas diferentes rodadas de negociações.

O Acordo já fora assinado pela diplomacia brasileira, representando o presidente da República, e tinha que ser admitido ou rejeitado em seu todo, com exceção dos acordos plurilaterais, em que a adesão seria voluntária, cujos textos nem acompanharam o conjunto dos acordos multilaterais da Ata Final enviados ao Congresso. 0 governo também se comprometera, por exigência constante da própria Ata, a ratificar o Acordo para que entrasse em vigor antes do iní- 
cio das operações da O M C, em janeiro de 1995.

Os elaboradores dos textos desses acordos tiveram o cuidado de inserir a impossibilidade de um Estado fazer ressalvas ou reservas na etapa da ratificação, ou seja, a proibição da hipótese de que algum Estado possa não concordar com algum dispositivo de um acordo, ou com um acordo por inteiro, ecolocar-seà margem de seu cumprimento. Aqui, o déficit para a soberania parecetambém evidente.

A mensagem presidencial, então, expôso assunto para o Congresso $\mathrm{N}$ acional de forma bastante restrita: ou o Brasil ratificava o Acordo por inteiro eda forma como foi elaborado, ou se situava fora da regulamentação do comércio internacional e pagaria caríssimo pelo custo dessa decisão, ficando até mesmo à margem da O M C como país não-signatário. Essa era a decisão a ser tomada. 0 mérito dos acordos constitutivos da A ta Final não estava em pauta. N ão cabia à sociedade representada apreciá-los, tampouco modificá-l los ou determinar sua ressal va àqueles pontos que pudessem prejudicar a estratégia nacional de desenvolvimento.

Tomando conhecimento do vastíssimo elenco de textos somente no momento de seu envio para iniciar o processo de ratificação, restava, pois, ao Congresso $\mathrm{N}$ acional, aceitar ou recusar todo o conjunto de acordos negociados pelo Executivo na Rodada U ruguai, sem dispor deestudos concernentes aos seus conteúdos e aos impactos que certamente teriam na sociedade brasileira, a não ser os depoimentos dos representantes do ministério do próprio governo, em particular, os da área di plomática.

Essa tensão entrea política internacional ea política doméstica, em especial, no que se refere aos princípios da democracia, mas também aos da soberania, de acordo com H eld (1995), coloca a questão de como compensar a defasagem entreo espaço de representação - no parlamento, onde representantes de segmentos sociais tentam maximizar seus interesses - eo espaço de decisão - no executivo, onde os governantes tentam alocar recursos e instituir políticas e programas para responder às demandas internas e externas.

A assinatura do Acordo era fundamental ao Governo para a inserção do Brasil no mundo gl obalizado, conforme as diretrizes da Rodada U ruguai, e para melhorar suas chances de competitividade. Fora do Acordo, o país seria marginalizado e ficaria em condições ainda mais difíceis na competição pel os mercados externos no processo deglobalização.

\section{Soberania e democracia}

Para Cox (1997), o significado mais amplo e geral da globalização refere-se à crescente conexão einterdependência - dos países - em escala mundial, sendo que esta conexão seria multidimensional, pois abrangeria aspectos de segurança, economia e bem-estar, ecologia, cultura e val ores de todas as espécies.

Segundo esse autor, a globalização fez com que a competitividade nos mercados mundiais se transformasse no objetivo número um das políticas de Estado. E o conjunto de medidas para al cançar este objetivo compreendia a desregulação dos controles econômicos efinanceiros, a privatização de empresas públicas, as restrições fiscais e a redução drástica dos gastos públicos com políticas sociais, entre outras receitas dos organismos multilaterais financiad ores (Cox, 1997).

Tal perfil de políticas de Estado, nas quais se inclui a imposição da austeridade via ajuste estrutural para os países periféricos, inviabilizaria as esperanças dos países do Terceiro M undo em construir políticas de bem-estar social e de evitar suas conseqüências, como 0 desemprego massivo, a crescente polarização social e 0 avanço da violência em todas as suas formas, que comprometeriam, de modo significativo, o processo de desenvolvimento da democracia interna (Cox, 1997).

Pode-se dizer que um bom sistema de regulamentação e controle sanitário é importante para uma política de bem-estar social e, também, que, nos países periféricos, el e sofre a mesma lógica de minimização em favor da competitividade econômica. Em termos econômicos, essa minimização favorece os países centrais que têm instituições mais fortes emeIhores estruturas de regulamentação e controles sanitários, motivo pelo qual seus produtos gozam de credibilidade adicional. Sem barreiras al fandegárias, estes entram facilmente nos mercados dos países em desenvolvimento, onde o controle sanitário é deficientee precário.

A rota contrária, no entanto, não é tão fácil. As agências de regulamentação e controles sanitários dos países centrais exigem rigorosos processos de qualidade para os produtos externos. Entretanto, a engenharia política brasileira já inventou o jeito: a discriminação negativa, isto é, os produtos para o consumo interno seguem os precários controles sanitários das instituições do Brasil, enquanto alguns produtos para os mercados estrangeiros 
seguem os regulamentos rigorosos das instituições dos países importadores. A democracia interna ainda não é suficiente para enfrentar esta questão.

Em relação à so berania, os acordos sanitários do GATT podem ser avaliados por essas diferentes abordagens. Sob o ponto de vista institucional - e globalista - é possível concluir que, por definir certos procedimentose regras para todos os estados, estes significam avanço em relação à situação anterior, na qual os estados mais fracos ficavam sujeitos a qualquer tipo de arbitrariedade por parte dos mais poderosos. Há uma institucionalização no plano internacional que constitui mais um foro de busca de entendimentos, contribuindo para diminuir a anarquia do ambiente internacional e, assim, ao menos formalmente, haveria mel hores possibilidades para os estados periféricos.

Por outro lado, éum acordo que deixa os estados mais poderosos perfeitamente à vontade para fixarem o nível de exigência que entendem ser o certo, pois dispõem de recursose mediações institucionais que lhes permitem justificar e sustentar, política e cientificamente, suas escolhas e seus interesses, filtrando as conseqüências indesejáveis. Da maneira como estão colocados os procedimentos nos acordos sanitários, os estados mais fracos ficam com imensa dificuldade de se constituírem interlocutores no mesmo plano dos estados centrais. No fundo, a determinação das medidas sanitárias segue a lógica da divisão do poder entre os estados nacionais do sistema internacional.

Enquanto não se constrói a democracia cosmopolita heldiana, é forçoso reconhecer que a internaci onalização tem causado crescentes prejuízos no plano da política interna. I sso se verifica tanto no aspecto da democracia liberal - da participação no processo decisório de construção de políticas de Estado voltadas ao bem-estar coletivo segundo objetivos nacionais - quanto no plano da soberania de cada nação, no sentido de tomar a si a decisão e condução do que acontece dentro de suas fronteiras.

0 processo de ratificação dos acordos do GATT no Congresso demonstra claramente que a discussão dos acordos e a adesão do Brasil a el es realizam-se em detrimento da democracia interna. Ainda mais, o Executivo usurpa o poder do Legislativo como foro de elaborações políticas sobre regulamentação de matérias do interesse de toda a sociedade.
São muito preocupantes as advertências de Cox (1997) acerca do esvaziamento do processo político de escol has entre al ternativas de desenvolvimento, além da redução da atividade política à programação e à gerência de projetos definidos al hures, em foros nos quais a hegemonia pertence aos estados centrais, como foi o caso dos acordos do GATT. Ainda mais preocupante éo conseqüente cetici smo que se desenvolve na população em virtude da incapacidade de a política interna enfrentar os problemas básicos de desem prego, corrupção e, ainda, a deterioração dos serviços básicos como a saúde e a segurança. A globalização das decisões, incluindo aqui a regulamentação de aspectos da vida nacional, gera descrédito nas autoridades políticas e apatia cívica em relação à participação e ao aperfeiçoamento do processo democrático. 0 vazio na dimensão da política deprime o movimento social, retira o vigor do processo participativo, principalmente, do segmento excluído, e tende a ser preenchido por outros movimentos, em geral, constitutivos da violência e da organização criminosa.

A soberania parece estar, da mesma forma, em processo de enfraquecimento face às tendências das relações internacionais. Aqui, os questionamentos aparentam ser maiores, porquanto se relacionam à fragilização do Estado, com a erosão de sua autoridade, e a um correspondente aumento da competência de organizações internacionais, como sugere Rosenau (1995).

Se, por um lado, o globalismo estimula os estados soberanos a responsabilizarem-se mais diante de suas populações e dos outros estados, por outro, ele perpetua as diferenças, pois retira a soberania das unidades, fazendoas trilhar os caminhos homogêneos propostos pelas agências multilaterais. As empresas transnacionais também exercem destacadíssimo papel nesse processo e acabam autonomizando-se das autoridades nacionais nos países periféricos.

No caso dos acordos do GATT, a análise mostra que os autores realistas são mais importantes para os países em desenvolvimento. $\mathrm{N}$ ão há como deixar de perceber que os interesses nacionais dos estados mais poderosos definiram a pauta e as linhas principais dos acordos, enfim, realizaram-se melhor. Seus interesses particulares são colocados na linguagem dos princípios universais como sendo valores compartilhados por toda comunidade 
internacional. O Acordo sobre Aspectos do Direito da Propriedade Intelectual Relacionados ao Comércio (ADPIRC), mais conhecido pela sigla em inglês TRIPS, também constante do Acordo do GATT, que dispõe sobre a proteção patentária de inovações tecnológicas, seria outro exemplo emblemático dessa estratégia.

As exigências dos acordos sanitários significam, por um lado, uma institucionalização no plano internacional que pode dificultar 0 arbítrio ao instituir normas comuns a todas as unidades. Por outro lado, determinam maior dificuldade à competitividade dos países menos desenvolvidos por sua fragilidade econômica, tecnológica e institucional, contribuindo para a eternização das diferenças.

Construir sistemas de regulamentação e controle sanitário voltados para a proteção dos cidadãos de um território definido, com autonomia face a outros estados para determinar as regras e as medidas necessárias a essa população parece ser, cada vez mais, al go difícil, somente suportado pelos estados mais poderosos. Para os cidadãos da periferia essa é uma situação de desconforto einconformidade.

\section{0 utros acordos e regulamentos internacionais de interesse sanitário}

O utros acordos internacionais têm grande importância para o controle sanitário, pois se relacionam direta ou indiretamente com o gerenciamento de riscos à saúde. São aqui apenas enumerados com o objetivo de aumentar a informação ao público e a consciência sobre suas implicações:

1) a Convenção da Basiléia - que define diretrizes para o transporte transfronteiriço de cargas perigosas; aborda igualmente o problema do destino seguro dos resíduos industriais tóxicos, vendidos ou doados, muitas vezes, aos países da América Latina, da Ásia ou da África pelas indústrias dos países desenvolvidos.

Sabe-se que os resíduos industriais são fontes inequívocas de contaminações - em particular, de superfícies e de lençóis freáticos - que trazem graves riscos à saúde. 0 caso da importação de baterias de carro usadas no Brasil é típico. Depois de aproveitados al guns componentes das baterias usadas, suas carcaças são abandonadas nos lixões ou aterros sa- nitários municipais, contaminando com chumbo muitos locais eáguas. 0 saturnismo e outras doenças não têm estatísticas precisas que permitam avaliar a magnitude do dano ambiental e sanitário envolvido.

2) o Acordo de M ontreal - que aborda o problema da camada de ozônio, busca diminuir o uso dos gases que causam sua destruição, em especial o cloro-flúor-carbono (CFC), bastante utilizado em muitos campos industriais, principalmente a fabricação de refriger adores e assemelhados, bem como em produtos (cosméticos, inseticidas, saneantes, etc.) do tipo spray.

Além das implicações ambientais, a destruição da camada de ozônio é um dos fatores comprovadamente determinantes do aumento do câncer de pele tanto no Brasil como em várias partes do mundo.

3) o Protocolo de K yoto - sobre o problema do aquecimento global, busca diminuir as emanações de gás carbônico (CO2) por meio de cotas máximas permitidas aos países, com o objetivo de estancar o aumento gradativo da temperatura média no planeta.

0 aquecimento global desequilibra todo o regime do clima - temperatura, geleiras, chuvase assim por diante-, comprometendo toda a ecologia e, em especial, o futuro das novas gerações. 4) o Programa Internacional de Controle de Substâncias Químicas - quebusca avaliar o risco das milhares desubstâncias químicas utilizadas industrialmente.

0 desvendamento dos efeitos sobre a saúde humana no que diz respeito ao uso de milhares de produtos químicos, certamente trará explicações acerca da ocorrência de muitas doenças principalmente, as crônicas- quehoje acometem as populações detodos os lugares do mundo. 0 Conselho Nacional de Pesquisas dos Estados Unidos estima que são conhecidas cerca de $5 \mathrm{mi}$ Ihões de substâncias químicas e que mais de 70 mil delas são hoje utilizadas comercialmente. Dessas, apenas 3,5 mil têm alguma consideração relacionada a suas implicações ambientaise $2 \mathrm{mil}$ têm estudos relacionados ao seu uso em alimentos. Para cerca de $80 \%$ das 70 mil substâncias não há qualquer estudo a respeito do risco à saúde (NRC, 1988).

5) a Convenção sobre DiversidadeBiológica que tem três principais objetivos: a conservação da diversidade biológica, a utilização sustentável de seus componentes eajustiça e eqüidadena divisão dos ben efícios do uso dos recursos genéticos. 
Essa Convenção talvez seja um dos mais importantes acordos da comunidadeinternacional, pois seus temas têm importância crucial para a manutenção das condições devida detodas as espécies naturais e poderiam servir defundamento para as políticas de desenvolvimento ederegulamentação em vários campos da vida social e econômica.

6) o Protocolo deCartagena - quefaz parte da Convenção da Diversidade Biológica e busca proteger a diversidade biológica dos riscos potenciais relacionad os aos organismos geneticamentemodificados, resultantes da biotecnologia moderna, estabeleceacordo de informação como procedimento para que os países manifestem concordância no que se referea importações de organismos geneticamentemodificados.

Esses acordo s internacionais podem ser percebidos como verdadeiros processos de regulamentação deriscos relacionados a temas degrande interesse para a saúde pública nacional einternacional. Além deles, negociados comumente pela área diplomática, existem outros processos regulatórios degrande importância para o controlesanitário, quesão negociadospor instâncias mais técnicas do Poder Executivo nacional:

a) Comissão do Codex Alimentarius, aprovada na Conferência da Organização da Alimentação e Agricultura (FAO), de 1961, e na Assembléia M undial da Saúde da Organização M undial da Saúde (WH O), de 1963, juntamente ao seu estatuto, quedefineos objetivos easfunções, eseu regimento, queestabelece os procedimentos detrabalho.

A função da Comissão do Codex Alimentariuséconstituir eexecutar o Programa Conjunto $\mathrm{FAO} / \mathrm{WHO}$ sobre $\mathrm{N}$ ormas Alimentares, quetem como objetivos: 1) proteger a saúde dos consumidores e assegurar práticas eqüitativas no comércio dealimentos; 2) coordenar todos os trabal hos relativos a normas al imentares empreendidas por organizações governamentais ou nãogovernamentais; 3) determinar a ordem de prioridades einiciar e dirigir a preparação de projetos de normas através de organizações apropriadas e com a ajuda destas; 4) finalizar as normas elaboradas conformeo item anterior e, depois de sua aceitação pelos governos, publicá-las em um Codex Alimentarius como normas regionais ou mundiais, junto às normas internacionais já finalizadas por outros organismos, em acordo com o item 2) anterior, sempreque seja possível; e, 5) modificar as normas publicadas, depois de estudo oportuno, à luz das circunstâncias.

Além das normas de produtos, o Codex con- tém normas gerais sobre: rotulagem dealimentos; aditivos alimentares; contaminantes; métodos de análises e amostragem; higiene dos alimentos; nutrição ealimentos para regimes especiais; sistemas de inspeção e certificação de importações eexportações de alimentos; resíduos de medicamentos veterinários nos al imentos; $\mathrm{e}$ resíduos de pragui cidas nos al imentos. Todas as normas aprovadas compõem o Codex Alimentarius eestão distribuídas em 13 volumes, os quais são classificados por tipos de al imentos, ecompreendem: 237 normas para produtos; 42 códigos de práticas de higiene ou tecnológicas; 185 agrotóxicos avaliados; 3.274 limites para resíduos de agrotóxicos; 25 diretrizes para contaminantes; 1.005 aditivos aval iados; e 54 medicamentos veterinários avaliados (Los logros del Codex, disponível em: <www.fao.org>).

b) Conferência Internacional sobre H armonização (ICH ), criada em 1990, mas com início em abril de 1991, quando foi estabel ecido um ComitêD iretivo composto de seis representantes oficiais - dois da Comissão Européia, dois da FD A/EU A e dois do M inistério da Saúde, TrabaIho eBem-Estar do Japão - ede seis representantes das respectivas federações das indústrias farmacêuticas. Autoridades do Canadá eda Suíçarepresentando a Área Européia de Livre Comércio -, bem como da Organização M undial da Saúde, participam como observadores da Conferência etêm assento no ComitêDiretivo.

A Conferência envolveagentes reguladorese representantes da indústria regulada como parcei ros iguais nas discussões científicas etécnicas dosprocedimentos, além detestes quesão requeridos para avaliar a segurança, qualidade e eficácia dos medicamentos. Busca a harmonização dos requisitos de licenciamento denovos medicamentos em seus mercados. 0 foco principal centra-se nos requerimentos relacionados aos novos fármacos que, em sua maioria, são desenvolvidos na Europa O cidental, Estados U nidos ou Japão, razão pela qual a Conferência definiu que a harmonização vale apenas para o registro nessas três regiões, embora o objetivo seja o de expandir seu uso a todas as partes do mundo.

Essa harmonização, uma iniciativa da indústria farmacêutica, tem o objetivo de diminuir os gastos com os processos regulatórios e o tempo para que os novos medicamentos entrem em comercialização. A Secretaria-ICH funciona em Genebra eé patrocinada pela Federação Internacional das Associações das I ndústrias Farmacêuticas (IFPM A - International Federation of Pharmacetical M anufacturers Associations). 
c) Harmonização de regulamentos técnicos de produtos de interesse para a saúde no M ercosul. Depois departiciparem de múltiplas formas eesforços regionais de integração e de cooperação entre os quais a Associação Latino-Americana de LivreComércio (Alalc), em 1960, ea sua sucessora, a Associação Latino-Americana de Integração (Aladi), em 1980 - , Argentina, Brasil, Paraguai e U ruguai constituíram um bloco de integração econômica chamado de M ercado Comum do Sul (M ercosul), mediante a assinatura do Tratado de Assunção em 1991. 0 Tratado deAssunção prevê: 1) a livre circulação de bens, serviços efatores produtivos entreos quatro países; 2) o estabelecimento detarifas aduaneiras comuns ea ado ção deuma política comercial comum com relação a outros estados; 3) a coordenação de políticas macroeconômicas esetoriais; e, 4) o compromisso de harmonizar suas legislações nas áreas correspondentes (Brasil, 1996).

O programa de liberação comercial prevêreduções tarifárias progressivas, lineares eautomáticas, acompanhadas da eliminação de restrições não tarifárias ou medidas de efeito equivalente. $\mathrm{N}$ esse sentido, para que os produtos e serviços circulem livremente pelo mercado integrado, torna-senecessária a harmonização de leis eregulamentos técnicos que possam significar barreiras não alfandegárias aos fluxos comerciais.

Os regulamentos sanitários são um dos tipos mais freqüentes e importantes de barreiras não alfandegárias. U m elenco grandede produtosé enquadrado em legislação especial, de natureza sanitária, porque tem componentes cujo consumo ou uso pode trazer riscos, de diferentes níveis, para a saúde dos indivíduos e da coletividade. Assim, regulamentados desta forma, temos, naárea de produtos: 1) os alimentos; 2) os medicamentos; 3) os artigos de higiene pessoal, os cosméticose perfumes; 4) os saneantes domiciliares; e, 5) os produtos deuso médico, hospitalar, laboratorial eodontológico.

0 trabal ho deharmonização dos regulamentos técnicos sobre esses produtos érealizado no âmbito das comissões temáticas que constituem - Subgrupo de Trabal ho n. 11 - Saúde, ligado ao Grupo M ercado Comum, o órgão executivo mais importante do M ercosul. A agenda de cada reunião detrabalho deve abordar os temas previstos nas pautas negociadoras.

0 tema dos alimentos, pela sua amplitudee complexidade, étratado, desdeo início, em 1991, em comissão específica, ligada ao SGT 3 - RegulamentosT écnicoseAvaliação de Conformidade. A Comissão de Alimentosécoordenada, no Bra- sil, pelo M inistério da Agricultura embora a participação técnica mais importante seja do M inistério daSaúde, por meio da vigilância sanitária.

Cada regulamento técnico harmonizado éremetido, pela comissão que fez o trabalho, ao SGT respectivo eesteo remete, como recomen dação, ao Grupo M ercado Comum (GM C) que, estando deacordo, edita uma resolução. U ma resolução do GM C significa um compromisso decadaEstado-parte em incorporá-la ao seu ordenamento jurídico, passando a vigorar em seu território.

d) Conferência Internacional de Autoridades Regulatórias, promovida pela Organização M undial da Saúde (OMS), a cada dois anos. N os últimos vinte anos já foram realizados nove encontros, o último deles na Alemanha, em abril de 1999, reunindo mais de 280 participantes oriundos de 90 países. N essa reunião foram abordados os seguintes temas: boas práticas de regulação; certificação de produtos objetos de comércio internacional segundo esquema da OM S; medicamentos falsificados; qualidade na regulamentação; zonas de livre comércio; estudos de utilização de medicamentos; esforços regionais sobre a regulação do tabaco; implicações da comunicação eletrônica na regulação; sessões para grupos especiais de pessoas como idosos e crianças; bioequivalência; medicamentos derivados do plasma humano; produtos naturais; emedicamentos essenciais - acesso eregulação.

e) Conferência Pan-Americana deH armonização da Regulamentação Farmacêutica, real izada pela Organização Pan-Americana da Saúde (OPS), desde 1997, seguindo a sistemática da OM S. A primeira Conferência realizou-seem novembro de 1997, a segunda em novembro de 1999, ambas em Washington (EUA), ea terceira em 2001. A organização das Conferências conta com a colaboração das entidades representantes dasindústrias: a Federação Latino-Americana da Indústria Farmacêutica (Fifarma), que representa majoritariamente as empresas multinacionais; ea Associação Latino-americana de Indústrias Farmacêuticas (Alifar), querepresenta as indústrias de capital nacional na região. Os representantes da indústria partici pam também detodos ostrabal hos da Conferência.

A I Conferência recomendou aos países latino-americanos a adoção das boas práticas de fabricação; a capacitação de inspetores de forma conjunta para alcançar parâmetros semelhantes; a implementação do reconhecimento mútuo; a exigência de testes de bioequivalência ebiodisponibilidade; mudanças nas condições de venda dos produtos; as boas práticas clínicas; o concei- 
to de países de referência; o fortalecimento das agências reguladoras; processos de harmonização por blocoseconômicos; ea aproximação com a Conferência Internacional de H armonização (ICH).

A II Conferência abordou principalmenteos temas dos testes de bioequivalência ebiodisponibilidade; as boas práticas clínicas; as boas práticas de fabricação; a falsificação de medicamentos; e a classificação de medicamentos (com e sem prescrição). Também foram abordados os temas da formação da Área de Livre Comércio das Américas (Alca), do processo deharmonização farmacêutica na Europa einformes sobrea 9a Conferência Internacional deAutoridades Reguladoras (ICDRA).

Embora sejam chamadas de Conferências Pan-Americanas de Harmonização da Regulamentação Farmacêutica, não há regimento para orientar o processo de harmonização, não são discutidas especialmente propostas deharmonizações etampouco há prazos ou compromissos dospaíses.

\section{Considerações finais}

A internacionalização da economia e seu contexto de conseqüências - intensificação das trocas comerciais e mudanças nas estratégias de produção (como terceirização, aumento de escala e concentração das fábricas) - mudaram as relações entre o comércio e a saúde, aqui entendida como a regulamentação e o controle sanitário. Para os sanitaristas, a questão é clara: a proteção e a segurança da população são preponderantes sobre os interesses comerciais. Para os economistas e empresários, as barreiras sanitárias são, antes, obstáculos ao desenvolvimento do comércio e devem ser limitadas ao estritamente necessário.

A própria Organização M undial da Saúde (OM S) está preocupada com os processos relativos a conflitos comerciais que são analisados e arbitrados na Organização M undial do Comércio (OMC) sem que se considere a existência de padrões ou de conhecimento técnico-científico sistematizado, disponível e adequado. As decisões acerca desses conflitos - que envolvem governos, empresas e consumidores - vão conforman do gradativamente uma espécie de jurisprudência eminentemente pragmática, que pode consagrar vantagens comerciais e novos protecionismos, justificados em considerações de duvidosa base científica e técnica, que tenham um impacto negativo sobre a saúde das populações ou prejudiquem o desenvolvimento ad equado das relações comerciais (OPS/OMS, 1997).

A OM S busca formalizar com a O M C um protocolo de cooperação técnica para atuar nessa área de preocupação, enten dendo que os governos, empresários e os consumidores devem esforçar-se para que se tenha níveis superiores de regulamentação, definição e adoção de padrões e de controle sanitário a respeito da comercialização de produtos e de seu impacto no ambiente (OPS/ OM S, 1999).

A valiações na linha realista a respei to das negociações dos regulamentos sanitários explicitam um processo em que os valores universais da lógica sanitária não são o fundamento e o determinante principal das posições dos delegados. Com maior ou menor ênfase, as preocupações com o aspecto econômico e os interesses nacionais determinam a busca, por meio da regulamentação sanitária, de vantagens relativas para os países mais desenvolvidos.

Além do mais, apesar de todas as regulamentações, harmonizadas ou não, sempre haverá a possibilidade de que um país necessite adotar medi das sanitárias que sejam diferentes ou mais rigorosas do que as existentes. 0 argumento formal é que deve haver justificação científica, ou seja, decisão coerente e consistente, derivada da adequada avaliação do risco envolvido, em todas as suas dimensões. Para isso, como já foi afirmado anteriormente, é extremamente necessária uma institucional idade especial izada, para que o país tenha força suficiente para afirmar sua decisão tanto no plano técnico como jurídico, político e administrativo.

Por outro lado, de acordo com o enfoque globalista, a normatividade no comércio internacional - fundamentada em regulamentos harmonizad os por blocos de integração regional, nas regras da O rganização M undial do Comércio, no Codex Alimentarius ou em acordos bilaterais entre países - estabelece-se gradativamente no sentido da construção de jurisprudência internacional, na qual as demonstrações e convencimentos mútuos acerca das necessidades de níveis apropriados de proteção sanitária às populações têm importância fundamental.

Entretanto, para além das preocupações 
sobre os reflexos (negativos) no espaço da democracia ou da soberania dos estados menos desenvolvidos, é necessário que se reflita mais profundamente sobre os acordos e processos de regulamentação sanitária internacional que, na mai or parte das vezes, não questionam as ten dências e os problemas de fundo que intervêm no risco sanitário. A avaliação e a gerência do risco são colocadas na estreita moldura da relação risco-ben efício (Griffiths et al., 1997), calculado apenas em termos biológicos, em lugar de uma visão mais completa, em que os objeti vos incluam perspectivas de longo prazo, modelos produtivos sustentáveis, questões culturais, sociais e éticas, ou seja, que incorporem certa exegese da tecnologia e da cadeia produtiva.

o Comitê do Codex sobre Resíduos de Pesticidas, por exemplo, trabalha para determinar os limites de resíduos destas substâncias nos alimentos. No entanto, não lida de modo adequado com temas tais como as doenças ocupacionais e os impactos dos agrotóxicos na água, no solo e ar (Avery, D rake e Lang, 1993). O mesmo raciocínio pode ser aplicado às drogas veterinárias, aos aditivos alimentares, à biotecnologia e assim por diante. É uma regulamentação ex post que tem grande cuidado em não interferir ou questionar as tecnologias que aumentam a produtividade. Avery et al. fizeram uma avaliação sobre os participantes dos trabaIhos de regulamentação e concluíram que predominam os del egados privados, representantes de empresas diretamente interessadas nos temas, em detrimento de delegados governamentais ou de organizações de defesa do consumidor.

É nessa mesma linha de crítica que autores como Porto e Freitas (1997) questionam as metodologias fragmentadas de avaliação de risco no campo do trabalho, propugnando novas abordagens teórico-metodológicas, mais integradoras com a dimensão ambiental mais geral, que possibilitem diagnósticos integrados e sínteses si stêmicas, em busca de políticas públicas mais globais de avaliação e gerenciamento de risco. O s mesmos autores preocupam-se com a velocidade da capacidade de inovação tecnológica no ramo da química, que coloca no mercado, a cada ano, entre mil e duas mil novas substâncias. A penas uma pequena parcela dessas novas substâncias tem avaliação minima- mente adequada sobre os riscos ao $\mathrm{H}$ omem e ao ambiente. Essas inovações tecnológicas, que alimentam o desenvolvimento industrial no ramo da química, vêm determinando um aumento dos riscos em velocidade bem superior à capacidade científica e institucional de avaliá-los e gerenciá-los.

Tomando como exemplo o que acontece na área dos al imentos, vê-se que a Comissão do Codex e o Acordo sobre M edidas Sanitárias e Fitossanitárias (AM SF) tratam os produtos principalmente como commodities e não como alimentos em sua dimensão total e em sua importância vital para os seres humanos. Seu processo segue as diretrizes ea lógica do sistema industrial de produção, que direciona hoje toda a produção agropecuária, e a el e responde mais do que à preocupação com os graves problemas do acesso da população à comida (food security) eà segurança sanitária (food safety).

Atualmente, as exigências do mundo são diferentes daquelas dos anos 60 , quando a "revolução verde" acenava com a abundância da produção mecanizada de alimentos para o mundo. Como foi debatido no Encontro da Terra (Earth Summit, realizado no Rio de Janeiro, em 1992), a importância do desenvolvimento sustentável e da proteção do ambiente tornou-se primordial. A Comissão do Codex precisa incorporar as novas necessidades, definindo novos fundamentos para sua estrutura, forma e doutrina de trabalho. A atual tecnologia produtiva tanto de alimentos primários como de industrializados, sem críticas e avaliações de seus fundamentos, tende a seguir um caminho que agrava os atuais problemas de segurança alimentar e segurança sanitária. A lógica básica do atual sistema produtivo, preocupada quase que exclusivamente com a dimensão econômica - aumento de produtividade -, demanda, de forma crescente, mais e mais pesqui sas e avaliações de risco e mais e mais regulamentações, sem deixar espaço para abordagens diferentes e de outra natureza.

Há muito conhecimento acumulado a respeito dos benefícios e prejuízos causados pela "revolução verde" dos anos 60, que deveria ser muito mais utilizado como balizamento dos trabalhos dos organismos internacionais de regulamentação. No Brasil, segue-se produzindo com o uso intensivo de substâncias químicas altamente tóxicas que 
são liberadas no ambiente, quando há evidências inequívocas de que a escassez da água já é problema sério em muitas partes do mundo. Como afirma Shiva (2001), deveríamos discutir agora a conservação da base produtiva, ou seja, o solo, a água, a biodiversidade. E como quer Visvanathan (FSP, 2001), redescobrir a reciprocidade da relação com a natureza e o verdadeiro sentido da "comida" em sua dimensão antropológica, sem deixar, necessariamente, de buscar o aumento de produtividade.

A discussão dos al imentos obtidos através de biotecnologia é outro alerta para uma possível ampliação dos debates acerca da avaliação e gerenciamento de risco. Muitos recursos estão sendo gastos na tentativa de regulamentar o uso e a rotulagem dos produtos da biotecnologia, enquanto a avaliação de risco não forneça informações mais completas dos efeitos danosos que podem gerar. Porém, essa discussão não pode ser restrita somente a sua dimensão toxicológica na moldura estreita do risco-benefício biológico, ou seja, se os al imentos geneticamente modificados apresentam ou não risco sanitário ao organismo humano. É hora de a Comissão do Codex fazer também análises do custo social e ambiental de longo prazo; de debater a relação do alimento (comida) com a perda da diversidade; da semente bioengenheirada ou a terminator, com a situação de dependência dos agricultores, ou melhor, da etapa agrícola, em relação às indústrias, donas das patentes de sementes e de pesticidas indicados a cada espécie. Griffiths et al. (1997), ao estudar a questão da regulamentação da biotecnologia, sugerem quebrar ou transcender à abordagem restrita da relação risco-benefício, pois ela não representa nem técnica e nem moralmente 0 enquadramento apropriado a estruturar as discussões e construir decisões a respeito do risco. A sugestão não precisa ser restrita ao tema da biotecnologia.

O Acordo AM SFS faz parte dos regulamentos da Organização Internacional do Comércio e preocupa-se especialmente em não permitir que as medidas sanitárias sejam utilizadas como barreiras disfarçadas ao comércio. Trata igualmente os desiguais, pois é muito mais fácil de ser cumprido ou aproveitado em direção aos interesses domésticos pelos países desenvolvidos, como vimos anteriormente.
A os processos internacionais de regulamentação farmacêutica pode-se aplicar análise semel hante. Sua ten dência é ad equar-se aos interesses das grandes empresas e do comércio internacional. A premência de sua incorporação na agenda das agên cias regulatórias, por exemplo, tem determinantes mais comerciais do que sanitários. $\mathrm{N}$ a América Latina, o grave problema da falta de acesso aos medicamentos e a também grave questão de seu uso irracional constituem temas recorrentes na agenda regional do gerenciamento do risco e da assistência farmacêutica, que poderiam ocupar, de forma preferencial, a energia de to dos os organismos interessados na saú de da população regional.

Os processos internacionais de regulamentação sanitária analisados incorporam, como regra, a interpretação mais "dura" do fenômeno da globalização, exatamente, a versão que deixa pouco espaço para a busca e implantação de alternativas, arranjos e mediações domésticas às exigências do mercado internacional. Comandados por essa espécie de determinismo que retira gradativamente aos estados nacionais o poder de decisão acerca do próprio destino, esses processos capturam as frágei s instituições nacionais dos países em desenvolvimento - 0 parlamento, as instâncias negociadoras da área das rel ações exteriores, as agências regulatórias e assim por diante.

Pode-se compreender que essa interpretação "dura" da globalização seja hegemônica no plano das organizações multilaterais da área econômica e financeira. Entretanto, é surpresa que essa mesma interpretação pareça ser dominante em organizações internacionais da área social como a O rganização M undial da Saúde/Organização Pan-Americana da Saúde e a Organização para a Ali mentação e Agricultura (FAO).

A Comissão do Codex tem suas raízes na O rganização da Alimentação e Agricultura (FAO) e na Organização M undial da Saúde (OMS), cujas missões são muito mais abrangentes e importantes sob o ponto de vista humano. Por isso, deveria buscar um caminho de maior autonomia em relação aos inter esses econômicos imediatos, dos paísesmembros e de suas empresas, pois deve zelar pela vida futura e pela imagem de organismos preocupados com a al imentação e a saúde pública mundiais. 


\section{Referências bibliográficas}

ADPIRC (TRIPS) 1994. Acordo sobre Aspectos dos Direitos de Propriedade Intelectual Relacionadas ao Comércio. Ata Final em que se incorporam os resultados da Rodada U ruguai de negociações multilaterais. M ensagem n. 498, de 1994, do Poder Executivo. Câmara dos Deputados, Brasil, Brasília.

AM S 1994. A cordo sobre a A plicação de M edidas Sanitárias e Fitossanitárias. Ata Final em que se incorporam os resultados da Rodada U ruguai de negociações multilaterais. M ensagem n. 498, de 1994, do Poder Executivo. Câmara dos D eputados, Brasil, Brasília.

Avery N, Drake M \& Lang T 1993. Cracking the Codex an analysis of who sets world food standars. $\mathrm{Na}$ tional Food Alliance Publication, Londres.

Bodstein RA 2000. Complexidade da ordem social contemporânea e redefinição da responsabilidade pública, pp. 63-97. In S Rozenfeld (org.). Fundamentos da vigilância sanitária. Fiocruz, Rio de Janeiro.

BTC 1994. Acordo sobre Barreiras Técnicas ao Comércio. Ata Final em que se incorporam os resultados da Rodada Uruguai de negociações comerciais multilaterais. M ensagem n. 498, de 1994, do Poder Executivo. Câmara dos Deputados, Brasil, Brasília.

Castels M 1999. Fim de milênio. A Era da Informação: economia, sociedade e cultura. Paz e Terra, São Paulo.

Cox R 1997. Democracy in hard times: economic globalization end the limits to liberal democracy, pp. 4971. In A McGrew (ed.). The transformation of democracy. Polity Press, Cambridge.

Fontanive VM 1994. Considerações sobre a apreciação da M ensagem n. 498, de 1994, pelo Congresso $\mathrm{N}$ acional. In Os acordos da Rodada U ruguai do GATT - estudo técnico. Câmara dos D eputados, Brasília. (Mimeo).

Griffiths A 1997. Gene escape, or pall of silence over plant biotechnology risk, pp. 153-181. In W Leiss \& D Powell (orgs.). Mad cows and mother's milk. M cGill-Q ueen's U niversity Press. M ontreal.

Held D 1995. Democracy and the global order. Polity Press, Cambridge.

H irst P \& Thompson G 1998. Globalização em questão - a economia internacional e as possibilidades de governabilidade. Ed. Vozes, Petrópolis.

Keohane R \& M ilner HV 1996. Internationalization and domestic politcs. Cambridge University Press, Cambridge.

Krasner SD 1995. Sovereignty and intervention, pp. 229-249. In G Lyons \& M M astanduno (eds.). Beyond W estphalia? State sovereignty and international intervention. The John H opkins U niversity Press, Baltimore.

Kratochwil F 1986. Of sistems, boundaries and territoriality: an inquiry into the formation of the state system. World Politics, vol. XXXIX. October. Princeton University Press, N ova Jersey.

Lyons G \& M astanduno M (eds.). 1995. Beyond W estphalia? State sovereignty and international intervention. The John Hopkins U niversity Press, Baltimore.

Milner HV 1997a. Interests, institutions and information: domestic politics and international relations. Princenton University Press, N ova Jersey.

M ilner H V 1997b. M aintaining international commitments in trade policy, pp. 345-369. In RK W eaver \& BA Rockman (eds.). Do institutions matter? The Brookings Institution, Washington, D.C.

OPS Organización Panamericana de la Salud 1999. II Conferencia Panamericana de la Armonización de Reglamentación Farmacéutica, 2 a 5 de noviembre de 1999. Informe Final. Washington, DC.

Presidência da República 1994. M ensagem n. 498, de 1994. Câmara dos Deputados, Brasília.

Porto M FS \& Freitas CM 1997. Análise de riscos tecnológicos ambientais: perspectivas para o campo da saúde do trabalhador. Cadernos de Saúde Pública 13(2).

Putnam RD 1988. Diplomacy and domestic politicsthe logic of two level games, pp. 4431-468. In PB Evans, HK Jacobson \& RD Putnam. D oubled-edged diplomacy - international bargainig and domestic politics. University of California Press, Berkeley.

Rosenau JN 1995. Sovereignty in a turbulent world. In G Lyons \& M M astanduno (eds.). Beyond Westphalia? State sovereignty and international intervention. The John H opkins U niversity Press, Baltimore.

Shah A 2001. Gobernando para obtener resultados en un mundo globalizado y localizado. Revista do Serviço Público 52(4):5-56.

Shiva V 2001. Biopirataria - a pilhagem da natureza e do conhecimento. Ed. Vozes, Petrópolis.

Artigo apresentado em 27/11/2002

A provado em 6/1/2003

Versão final apresentada em 26/2/2003 